\title{
Facultative catadromy in American eels: testing the conditional strategy hypothesis
}

\author{
Isabel Thibault ${ }^{1, *}$, Julian J. Dodson ${ }^{1}$, François Caron ${ }^{2}$, Wann-Nian Tzeng ${ }^{3}$, \\ Yoshiyuki Iizuka ${ }^{4}$, Jen-Chieh Shiao ${ }^{5}$
}

\author{
${ }^{1}$ Département de Biologie, Québec-Océan, Université Laval, Québec, Québec G1K 7P4, Canada \\ ${ }^{2}$ Ministère des Ressources Naturelles et de la Faune, 3950 Boulevard Harvey, Jonquière, Québec G7X 8L6, Canada \\ ${ }^{3}$ Institute of Fisheries Science, College of Life Science, National Taiwan University, Taipei, Taiwan 106, ROC \\ ${ }^{4}$ Institute of Earth Sciences, Academia Sinica, PO Box 1-55, Nankang, Taipei, Taiwan 115, ROC \\ ${ }^{5}$ Institute of Oceanography, College of Science, National Taiwan University, Taipei, Taiwan 106, ROC
}

\begin{abstract}
Analyses of otolith strontium:calcium (Sr:Ca) ratios in 162 American eels Anguilla rostrata of the St. Jean River watershed in eastern Canada demonstrated the co-existence of 6 migratory patterns, including freshwater and brackish water residence, and the predominance of an amphidromous migratory behavior. We tested the hypothesis that the choice of a particular life-history tactic may be controlled by a conditional strategy with status-dependent selection. This prediction was not supported because migratory patterns did not vary as a function of individual size, age and/or sex of eels prior to migration. However, we demonstrated that the utilisation of the estuarine brackish environment, more productive than the freshwater river and lake, resulted in a higher growth rate. Freshwater yellow eels, the typical catadromous tactic, were rare and experienced lower growth rates. Moreover, we suggest that freshwater overwintering periods are not recorded in otoliths owing to the cold winter climate that occurs at northern latitudes. Thus, Sr:Ca ratio patterns that show brackish residence may in some cases hide a seasonal migration between fresh and brackish habitats.
\end{abstract}

KEY WORDS: Anguilla rostrata · Otolith microchemistry • Migratory patterns • Amphidromy · Catadromy $\cdot$ Conditional strategy $\cdot$ Growth $\cdot$ Biological characteristics

\section{INTRODUCTION}

Eel species of the genus Anguilla are usually considered as catadromous because they spawn in marine waters and juveniles (yellow stage eels) grow in freshwater habitats following a long migration from the spawning area (several thousands of kilometres in temperate zones). However, the existence of yellow eels in brackish estuaries, tidal creeks, lagoons and coastal waters has been reported for many years (Hansen \& Eversole 1984). Migrations of yellow eels between freshwater and brackish water environments have also been observed in many regions, especially in the Canadian Maritime provinces (Medcof 1969, Jessop 1987). Even if these migrations are short $(\sim 10 \mathrm{~km})$ compared with the migrations of silver eels and leptocephalus larvae, they are of considerable importance because they occur during the prolonged growth stage (the yellow eel stage) and involve switching between environments that are completely different in terms of salinity, temperature, substrate, depth, and a large number of other environmental conditions.

With the development of techniques of microchemical analysis of otoliths, it is now possible to document migrations between different habitats throughout the entire life of individual fish. One of the most widely used techniques is the interpretation of variations in the strontium:calcium ( $\mathrm{Sr}: \mathrm{Ca}$ ) ratio in otoliths, because strontium increases with salinity and the molar ratio of $\mathrm{Sr}$ :Ca is 4.8 times less in freshwater than in salt water (Campana 1999). Therefore, Sr:Ca ratios can be used to provide information about a fish's past environmental history, because Sr:Ca values measured in otoliths can be associated with water masses of different salin- 
ities (Secor \& Rooker 2000). In eels, it has not been clearly demonstrated whether it is salinity (Tzeng 1996) or the Sr:Ca ratio in water (Kraus \& Secor 2004, Elsdon \& Gillanders 2005) that primarily determines the incorporation of $\mathrm{Sr}$ into the otolith. However, because Sr concentrations in water are generally correlated with salinity, the use of otolith Sr:Ca ratios in interpreting migratory history of eel across environments of differing salinity is justified (Shiao et al. 2006). Following otolith Sr:Ca ratio analyses, several authors argued that anguilid eel species should no longer be considered as obligatory catadromous because both brackish and seawater resident eels exist in addition to eels that migrate 1 or more times between habitats of different salinities during their growth phase (Tzeng et al. 2000, Tsukamoto \& Arai 2001).

Recently, Daverat et al. (2006) compared life histories of 3 species of temperate eels (Anguilla anguilla, $A$. rostrata and $A$. japonica) using otolith $\mathrm{Sr}$ :Ca ratio analyses. They observed facultative catadromous behavior in all 3 species. Moreover, they observed that life-history patterns were similar but present in different proportions among the 3 species, which is consistent with the review presented by Lamson et al. (2006). Daverat et al. (2006) also demonstrated that brackish water and saltwater residency in estuarine and coastal environments increased with latitude relative to other life-history tactics.

Although it appears that the migratory patterns of temperate eel species are far more flexible than previously believed, the question remains as to why some eels grow exclusively in freshwater whereas others grow in part or exclusively in brackish/marine habitats. We hypothesized that migratory patterns of eels during the yellow stage are controlled by a conditional strategy. The conditional strategy implies the existence of 2 or more tactics (phenotypes) that are expressed by the same genotype, but under different conditions, and present unequal fitness values (Gross 1996). The adoption of one tactic rather than another depends on the individual's status, or condition, compared with conspecifics. The tactic that procures the better fitness as a function of its own condition will develop. Among diadromous fishes, a conditional strategy may be involved in cases where 2 or more migratory patterns occur within a population. For example, in many species of salmonids, anadromous individuals that migrate to sea for growth co-exist with freshwater residents within the same population and, in several cases, the dichotomy in migratory behavior is determined by individual size (e.g. Thériault \& Dodson [2003] and references therein).

To test the hypothesis of a conditional strategy underlying the variable migratory patterns of juvenile eels, we studied the sub-population of American eels
Anguilla rostrata in the St. Jean River (Québec, Canada). In this river, a downstream migration of an estimated 15000 to 41000 yellow eels of sizes varying between 123 and $640 \mathrm{~mm}$ has been documented each spring since the installation of a rotary trap (fish wheel) in 2002 to monitor the spring outmigration of Atlantic salmon Salmo salar smolts (Caron et al. 2005). A tagging and telemetry study demonstrated that a portion of those migrants left the freshwater part of the river to feed in the brackish estuary until fall, and probably moved back to the river for overwintering. In addition, some eels remained in the river year-round, whereas others were suspected to be brackish water residents (Thibault et al. 2007). We thus determined the migratory patterns of eels within the St. Jean River watershed over their entire life cycle by analysing otolith $\mathrm{Sr}$ :Ca ratios. Six migratory patterns were observed: freshwater residence, brackish water residence, and 4 distinct amphidromous or 'nomadic' behaviors. The same migratory patterns were previously documented for this and other temperate eel species using similar techniques of microchemistry analysis (Daverat et al. 2006).

To determine if migratory patterns of yellow stage eels are controlled by a conditional strategy, we evaluated whether migratory patterns varied in terms of direction, timing or occurrence as a function of individual size, age and/or sex (status-dependent selection) of eels. Specifically, we predicted that slow-growing eels would migrate to the brackish water habitats, considered to be more productive than the river (Gross 1987, Tsukamoto \& Arai 2001), to promote their growth. Also, we predicted that males would use brackish habitat more (in terms of occurrence and over their life-time) than females (Helfman et al. 1987). Morrison et al. (2003) suggested that the growth rate observed in American eels in the Hudson River was a consequence rather than a cause of variable migratory patterns. We thus determined the consequences of the different migratory patterns observed on biological characteristics. We predicted that eels using the more productive brackish water habitat for foraging would show higher growth rates than freshwater yellow eels.

\section{MATERIALS AND METHODS}

Study area. The St. Jean River watershed $\left(1134 \mathrm{~km}^{2}\right)$ is located on the Gaspé Peninsula $\left(48^{\circ} 46^{\prime} \mathrm{N}, 64^{\circ} 26^{\prime} \mathrm{W}\right)$ in eastern Québec, Canada (Fig. 1). The river originates in the Chic-Choc Mountains and flows $115 \mathrm{~km}$ to discharge into a $5.8 \mathrm{~km}^{2}$ bar-built brackish estuary that opens into the Bay of Gaspé. The river bed is composed of sedimentary rocks, which maintain a basic $\mathrm{pH}$. Water temperatures vary from 0 to $\sim 25^{\circ} \mathrm{C}$ throughout the sys- 


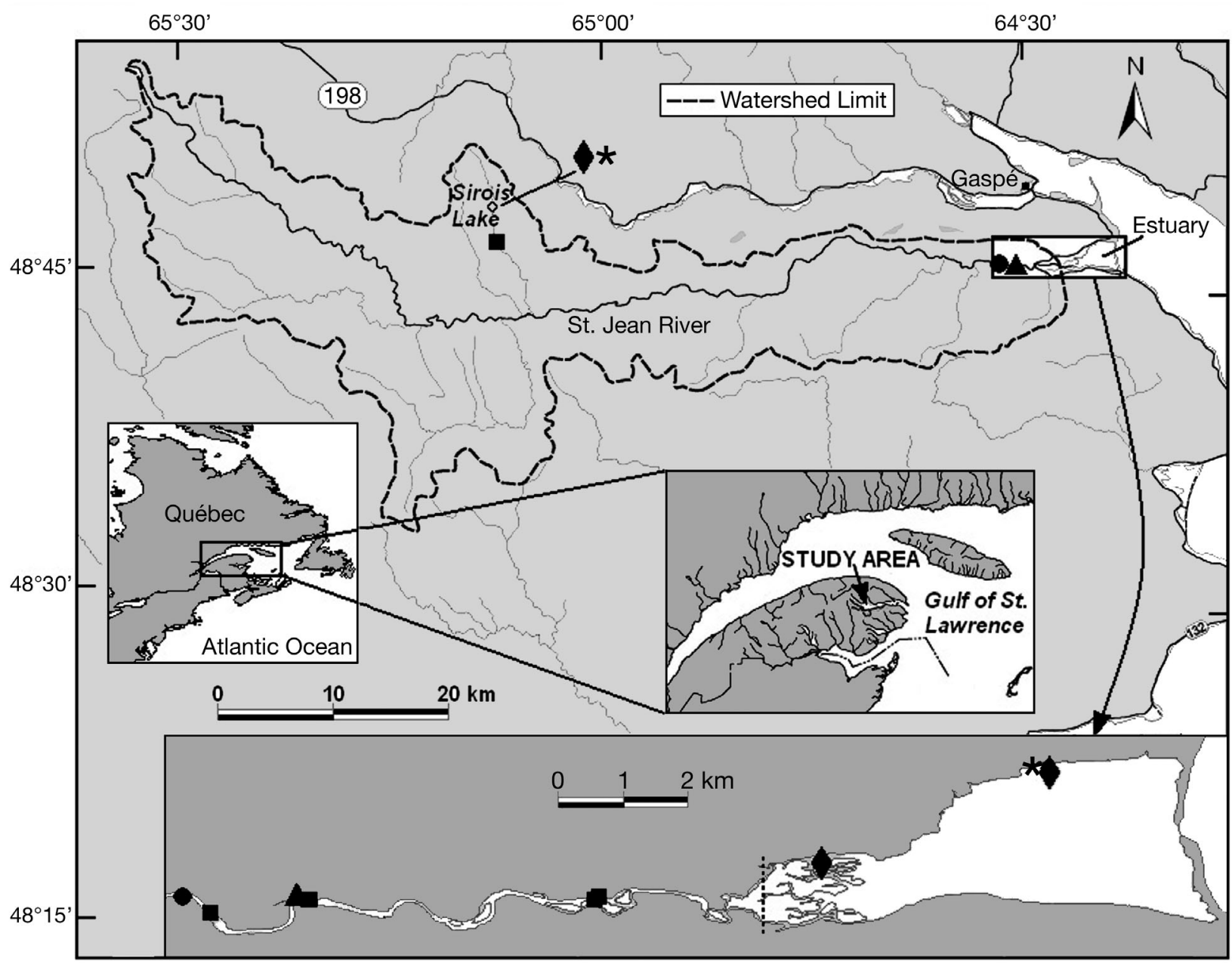

Fig. 1. St. Jean River watershed, Gaspé Peninsula, Québec (Canada), and capture locations of American eels Anguilla rostrata. $\checkmark$ : Hoop nets; *: minnow traps; $\boldsymbol{\square}$ : electrofishing stations; $\boldsymbol{\Delta}$ : fish wheel; $\bullet$ : partial counting fence. Vertical dashed line in lower inset indicates the tidal limit

tem. Salinity varies from 0 to $28 \%$ in the estuary, according to tide, season and sectors. In this part of the watershed, temperatures may be as low as $-0.3^{\circ} \mathrm{C}$ during winter owing to high salinities. Our study area extended from the estuary to Sirois Lake ( 16 ha) situated $80 \mathrm{~km}$ upstream from the river mouth. In our study site, $\mathrm{Sr}$ :Ca ratio values in water were approximately 7 times greater in brackish than in freshwater habitats, allowing us to discriminate between otolith $\mathrm{Sr}$ :Ca ratios incorporated in the 2 environments (Kraus \& Secor 2004).

Sampling and measures. Between May and September 2004, a total of 2358 yellow and silver American eels were captured in the St. Jean River, its estuary and Sirois Lake using hoop nets, minnow traps, a partial counting fence, electrofishing and a fish wheel located $7 \mathrm{~km}$ from the river's mouth (Fig. 1). Almost all of the downstream migrants (yellow eels in spring and silver eels in fall) were captured in the fish wheel. A total of 162 eels $(\geq 135 \mathrm{~mm})$ from all sites were sampled for otolith Sr:Ca ratio analyses and biological measures. Our sampling did not reflect the proportion of eels among the different sectors of the St. Jean watershed: we sampled few eels in the estuary compared with their absolute abundance.

Sampled eels were first measured $( \pm 1 \mathrm{~mm})$ and weighed $( \pm 0.1 \mathrm{~g})$. They were then sexed by macroscopic observation of gonads, and when no gonads were visible they were classified as sexually undifferentiated eels. Sex was also confirmed by microscopic observation for 18 males and 27 females. Sagittal otoliths were extracted. One otolith per eel was used for age determination (3 readers) and back-calculations. This otolith was cleaned and embedded in epoxy, ground to the core and polished. The section was then etched with 5\% EDTA and colored with $0.01 \%$ toluidine blue before observation of annual rings under a dissecting microscope. The second otolith was cleaned with distilled water to minimize chemical 
contamination, then dried (in air) and conserved in plastic eppendorf tubes until Sr:Ca ratio analyses (see below). Almost all eels were yellow stage, but we identified 18 silver eels by skin coloration and date of capture.

Otolith preparation and microprobe analysis. Otoliths were embedded in resin, ground and polished on the sagittal plane until the core was exposed. An electron probe microanalyser (EPMA, JXA-8900R, JEOL) with a wavelength dispersive X-ray spectrometer (WDS) was used to obtain a transect of $\mathrm{Sr}$ and Ca concentrations measured along an axis from the core of the otolith to the edge at $10 \mu \mathrm{m}$ intervals. Beam conditions were $15 \mathrm{keV}$ for the acceleration voltage and $3 \mathrm{nA}$ for the current, and a $5 \times 4 \mu \mathrm{m}$ rectangular scanning beam was used. This analysis provides a life-history transect that presents otolith $\mathrm{Sr}: \mathrm{Ca}$ ratio variations throughout life, as otoliths grow continuously.

Otolith Sr:Ca interpretation. The interpretation of $\mathrm{Sr}$ :Ca ratio life-history transects in terms of patterns of habitat use was based on field validations, a survey of the literature and analyses of other fish species (Thibault 2006). The threshold Sr:Ca ratio demarcating fresh from brackish water habitats was established at between $3.5 \times 10^{-3}$ and $4 \times 10^{-3}$ (Thibault 2006). As originally reported in Daverat et al. (2006), we defined 6 migratory patterns that could be divided into 2 general categories of movement: residency (in either freshwater or saline habitats) and amphidromy (or 'nomadic' behavior) (Table 1, Fig. 2).

Length back-calculations. To determine if individual size influenced alternative migratory patterns, we back-calculated eel size to the age of habitat switch (migration) as determined from otolith $\mathrm{Sr}$ :Ca ratios. Otolith radius and distances between annuli and the core were measured along the longest radius with image analysis software (SigmaScan Pro v. 4). Otolith image quality was poor for 21 eels, so only 141 eels were analysed. However, to examine the body length-otolith radius relation (TL-OR), we included data from 18 additional eels from the same sampling survey of the St. Jean River system. To back-calculate size at age, we used the 'body proportional hypothesis' technique (BPH) proposed by Jessop et al. (2006). The regression coefficients of the TL-OR relation $\left(\log _{10} \mathrm{TL}\right.$ $[\mathrm{mm}]=1.1146 \times \log _{10} \mathrm{OR}[\mathrm{mm}]+2.8174 ; \mathrm{n}=159, \mathrm{r}^{2}=$ 0.89) were used to define the $\mathrm{BPH}$ back-calculation equation

$$
\log 10 L_{i}=\left[\left(c+d \log _{10} O_{i}\right) /\left(c+d \log _{10} O_{c}\right)\right] \log _{10} L_{c}
$$

where $c$ is intercept and $d$ slope of the TL-OR regression, $L_{i}$ and $O_{i}$ are body length and otolith radius when age is $i$, and $L_{C}$ and $O_{c}$ are body length and otolith radius at capture. Back-calculations were restricted to ages 1 to 6 because almost all habitat switches occurred before $7 \mathrm{yr}$ of age. The annual instantaneous growth rate was calculated (length at age t $_{t+1}-$ length at age $t$ ) for these first years of life.

Data analyses. All the statistical analyses were executed in $\mathrm{SAS}^{\circledR}$ System v. 8 (SAS 2001). When ANOVA analyses were performed, we tested for residual normality and variance homogeneity and transformed data if necessary. When normality could not be achieved, we used the non-parametric Kruskal-Wallis ANOVA.

Testing the conditional-strategy hypothesis: Kolmogorov-Smirnov analyses were used to compare back-calculated eel size distributions prior to the age at habitat switch (migration), according to the eels' location (fresh vs. brackish water). To determine if age at habitat switch varied among migratory patterns $\left(A_{F B}, A_{B F}\right.$ and $A_{F B F}$, see Table 1), we performed a Kruskal-Wallis ANOVA. Using an ANOVA, we determined if size at habitat switch was the same among migratory patterns $\left(\mathrm{A}_{\mathrm{FB}}, \mathrm{A}_{\mathrm{BF}}\right.$ and $\left.\mathrm{A}_{\mathrm{FBF}}\right)$ for a given age. The sex distribution among migratory patterns and the age at habitat switch $\left(\mathrm{A}_{\mathrm{FB}}, \mathrm{A}_{\mathrm{BF}}\right.$ and $\left.\mathrm{A}_{\mathrm{FBF}}\right)$ among sexes were analysed with chi-square tests. Using a KruskalWallis ANOVA, we determined if the number of eels that underwent a habitat switch $\left(\mathrm{A}_{\mathrm{FB}}, \mathrm{A}_{\mathrm{BF}}\right.$ and $\left.\mathrm{A}_{\mathrm{FBF}}\right)$ varied among years. Finally, we determined if the direction of the movement was related to the year with the Kolmogorov-Smirnov procedure.

Consequences of the migratory patterns: To determine the influence of the life-history tactic on biologi-

Table 1. Anguilla rostrata. Description of 6 life-history patterns determined by otolith Sr:Ca ratio analyses on 162 eels captured the St. Jean River watershed

\begin{tabular}{|lcl|}
\hline Life-history pattern & Acronym & \multicolumn{1}{c}{ Description } \\
\hline Residency & $\mathrm{FR}$ & $\begin{array}{l}\text { Residence in freshwater. Entrance in freshwater between Year 1 (elver mark) and Year 2 } \\
\text { Residence in brackish habitat }\end{array}$ \\
& $\mathrm{BR}$ & Residence in brackish environment for more than 2 yr, then movement into freshwater \\
Amphidromous & $\mathrm{A}_{\mathrm{BF}}$ & Residence in freshwater then movement to brackish habitat \\
behavior & $\mathrm{A}_{\mathrm{FB}}$ & Freshwater residence, movement to brackish estuary then movement to freshwater \\
& $\mathrm{A}_{\mathrm{FBF}}$ & Frequent movements between habitats, with no defined pattern \\
& $\mathrm{A}_{\mathrm{ND}}$ & \\
& &
\end{tabular}




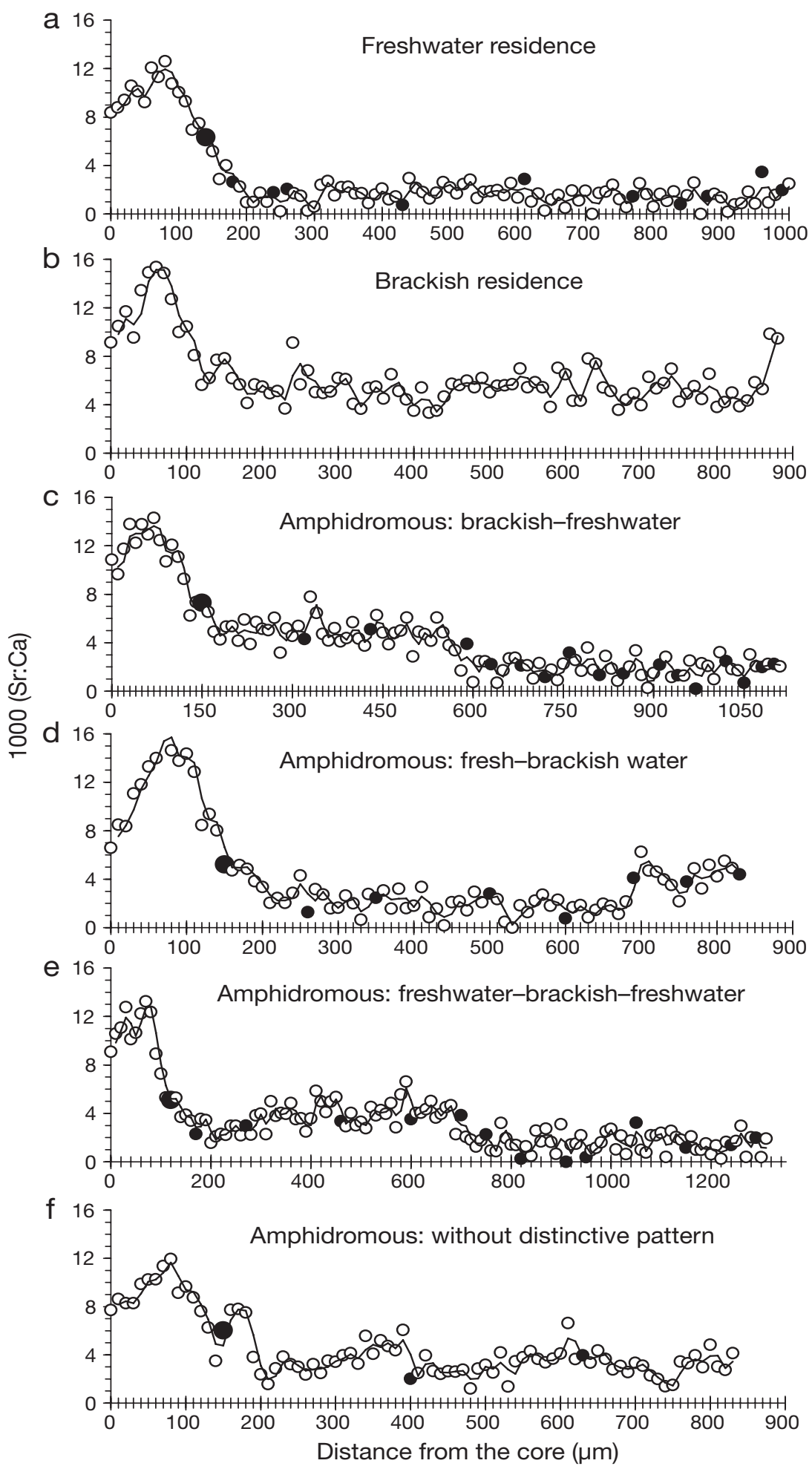

Fig. 2. Anguilla rostrata. Sr:Ca ratio transects along the otolith radius, from core to edge, illustrating 6 migratory patterns: (a) FR, (b) BR, (c) $\mathrm{A}_{\mathrm{BF}}$, (d) $\mathrm{A}_{\mathrm{FB}}$, (e) $\mathrm{A}_{\mathrm{FBF}}$, (f) $A_{N D}$. Sr:Ca ratio patterns were interpreted point-by-point from the elver check to the otolith edge with 2-point smoothed averages, according to a threshold of $3-4 \times 10^{-3}$ between fresh and brackish water masses. When only 1 point was located above or under the $\mathrm{Sr}$ :Ca ratio threshold, it was not taken into account. -: Annuli; : elver check (first year) (for eel [b] otolith was not clear enough to allow a correct age determination). Sr:Ca ratio peak observed before $100 \mu \mathrm{m}$ corresponds to metamorphosis from leptocephalus to glass eel (Tzeng 1996) cal characteristics, we regressed the different biological measures on age for each migratory pattern. We used 2-factor ANOVA (stage, sex, stage $\times$ sex) to determine if we could group all sexes and maturation stages in the analyses of biological characteristics. Length and weight varied in relation to stage and sex (all $p<0.05$ ). Since the number of silver eels, males and sexually undifferentiated eels was low, we analysed only yellow female eels. The significance of all the relationships was tested with the regression procedure. For both biological characteristics, regressions for $A_{F B F}$ eels (see Table 1) could not be completed because there were only 3 specimens in that category. Slopes among significant regressions were compared with a 2-factor ANCOVA (age, migratory pattern, age $\times$ migratory pattern). When slopes were similar, migratory patterns were pooled. Eels were then divided into 2 groups for length-at-age regression: eels that experienced brackish water for the major part of their life cycle and eels that lived in freshwater for a long period of time. We performed the same exercise for weight-at-age regression, except that $A_{F B}$ (see Table 1) eels were treated separately because their regression slope was not significantly different from those of the other migratory patterns. Finally, we compared backcalculated eel size distributions after the age-at-habitat switch, according to eels' location (freshwater vs. brackish water), with Kolmogorov-Smirnov analyses.

\section{RESULTS}

\section{Migratory patterns during the growth phase}

Among the 162 eels sampled throughout the watershed, eels captured in Sirois Lake and in the river during summer were almost all FR ( $\mathrm{n}=$ 15 and 6 respectively) or $\mathrm{A}_{\mathrm{BF}}(\mathrm{n}=18$ and 2 respectively; Table 2), whereas the estuary sample was dominated by $\mathrm{BR}(\mathrm{n}=29)$ and $\mathrm{A}_{\mathrm{ND}}(\mathrm{n}=16)$. Eels cap- 
tured in the river during the spring downstream migration were composed mainly of BR (66\%) and included more brackish resident eels than found in the estuary sample. There was only 1 FR among the eels captured during the spring migration: a 24 yr old female. In contrast, eels captured at the same location during the fall downstream migration were almost all FR or $\mathrm{A}_{\mathrm{BF}}(\mathrm{n}=$ 18 and 5 respectively).

Overall, amphidromy was the most represented migratory pattern in the sample $(42 \%$ of the eels, compared with 38 and $20 \%$ for BR and FR respectively). Most amphidromous eels had an $A_{B F}(40 \%)$ or $A_{N D}$ (41\%) migratory behavior. The only $A_{F B F}$ eels included 2 female yellow eels aged 14 and $20 \mathrm{yr}$ and 1 male silver eel. We found the same proportion of amphidromous eels in the estuary as in freshwater. However, amphidromous eels captured in the river were all caught in the lower $7 \mathrm{~km}$ of the river (in or downstream of the fish wheel trap). In contrast, FR eels were all captured upstream in the river and in Sirois Lake. Finally, for 47 eels, the Sr:Ca ratio at the otolith periphery did not represent the salinity prevalent at the capture site. These apparently erroneous peripheral ratios were more frequent in eels captured in the river during spring, especially those eels with otoliths characterized by the BR migratory pattern.

\section{Testing the conditional-strategy hypothesis}

Body length data obtained from back-calculations were compared between (1) eels exhibiting FR and BR life cycles, (2) BR and $A_{B F}$ eels and (3) FR eels and eels exhibiting $A_{F B}$ or $A_{F B F}$ life cycles. Because FR eels entered freshwater before Year 2, the first comparison was made at Age 1. As the majority of habitat switches experienced by amphidromous eels occurred between 2 and 3 yr of age or between 3 and 4 yr of age (Table 3), we conducted separate comparisons for the 2 age groups. Eels that changed habitat earlier or later were not numerous enough to permit comparisons for other age groups (less than 5 eels per age group). In all cases, before changing habitat, eels were similar in size to eels that did not switch habitats (Kolmogorov-Smirnov, all $p \geq 0.08$ ). However, because our sample size for the third comparison (freshwater resident vs. amphidromous eels) was small ( $\mathrm{n} \leq 5$ for amphidromous eels), the latter comparison was statistically weak. The age-athabitat switch was the same among $\mathrm{A}_{\mathrm{FB}}, \mathrm{A}_{\mathrm{BF}}$ and $\mathrm{A}_{\mathrm{FBF}}$ eels (Kruskal-Wallis test, 1.77, p = 0.41), e.g. around Age $3(49 \%$ at Age $2+, 23 \%$ at Age $3+)$. Size at the time of switching habitats did not vary with the migratory pattern for eels that migrated at the same age (ANOVA; Age 2 to 3: $p=0.68$; Age 3 to $4: \mathrm{p}=0.67$ ).

Table 2. Anguilla rostrata. Frequency of different migratory patterns among capture sites as a function of sex. F: female, M: male, I: sexually undifferentiated; FR: freshwater residence, BR: brackish water residence, $A_{B F}$ : brackish then freshwater residence, $A_{F B}$ : fresh then brackish water residence, $A_{F B F}$ : movement from freshwater to brackish water then to freshwater, $A_{N D}$ : migration between both habitats without a defined pattern

\begin{tabular}{|c|c|c|c|c|c|c|c|c|c|c|c|c|c|c|c|c|c|c|c|c|}
\hline \multirow[t]{2}{*}{ Salinity } & \multirow[t]{2}{*}{ Sector } & \multirow[t]{2}{*}{ Sampling time } & \multicolumn{3}{|c|}{ FR } & \multicolumn{3}{|c|}{$\mathrm{BR}$} & \multicolumn{3}{|c|}{$A_{B F}$} & \multicolumn{3}{|c|}{$A_{F B}$} & \multicolumn{3}{|c|}{$A_{F B F}$} & \multicolumn{3}{|c|}{$\mathrm{A}_{\mathrm{ND}}$} \\
\hline & & & F & M & I & $\mathrm{F}$ & M & I & $\mathrm{F}$ & $\mathrm{M}$ & I & $\mathrm{F}$ & $\mathrm{M}$ & I & F & $\mathrm{M}$ & I & $\mathrm{F}$ & $\mathrm{M}$ & I \\
\hline \multirow[t]{4}{*}{ Freshwater } & Sirois Lake & Summer & 12 & 2 & 1 & 0 & 0 & 0 & 16 & 0 & 2 & 0 & 0 & 0 & 2 & 0 & 0 & 1 & 0 & 0 \\
\hline & River & Spring migration & 1 & 0 & 0 & 25 & 4 & 2 & 1 & 0 & 0 & 5 & 1 & 0 & 0 & 0 & 0 & 6 & 2 & 0 \\
\hline & & Summer & 2 & 2 & 2 & 0 & 0 & 1 & 1 & 0 & 1 & 0 & 0 & 0 & 0 & 0 & 0 & 0 & 0 & 1 \\
\hline & & Fall migration & 4 & 7 & 0 & 0 & 0 & 0 & 1 & 3 & 1 & 1 & 0 & 1 & 0 & 1 & 0 & 2 & 0 & 0 \\
\hline Brackish & Estuary & Summer, fall & 0 & 0 & 0 & 24 & 1 & 4 & 0 & 0 & 1 & 2 & 0 & 0 & 0 & 0 & 0 & 12 & 2 & 2 \\
\hline Total & & & 19 & 11 & 3 & 49 & 5 & 7 & 19 & 3 & 5 & 8 & 1 & 1 & 2 & 1 & 0 & 21 & 4 & 3 \\
\hline
\end{tabular}

Table 3. Anguilla rostrata. Age when amphidromous eels switched between 2 habitats of different salinities. Number of backcalculated eels given in parenthesis when back-calculations were not completed for every eel

\begin{tabular}{|c|c|c|c|c|c|c|c|c|}
\hline \multirow{2}{*}{$\begin{array}{l}\text { Movement } \\
\text { description }\end{array}$} & \multirow{2}{*}{$\begin{array}{c}\text { Migratory } \\
\text { pattern }\end{array}$} & \multicolumn{7}{|c|}{ - Age (yr) of habitat switch- } \\
\hline & & 1 to 2 & 2 to 3 & 3 to 4 & 4 to 5 & 5 to 6 & 6 to 7 & 7 or more \\
\hline Brackish to & $\mathrm{A}_{\mathrm{BF}}$ & 0 & $16(14)$ & $7(4)$ & 2 & 1 & 0 & 1 \\
\hline freshwater & $A_{F B F}$ & 0 & 0 & 0 & 2 & 0 & 1 & 0 \\
\hline Fresh to & $\mathrm{A}_{\mathrm{FB}}$ & 2 & 3 & 2 & 0 & 2 & 0 & 1 \\
\hline brackish water & $\mathrm{A}_{\mathrm{FBF}}$ & 0 & 2 & 1 & 0 & 0 & 0 & 0 \\
\hline
\end{tabular}


Among the 162 eels analysed for otolith Sr:Ca ratios, 118 were females, 25 were males and 19 were sexually undifferentiated. Females were found in the same proportions in the river, lake and estuary (Table 2). Inversely, almost all males were captured in freshwater, with $80 \%$ of males captured in the river. However, there was no sexual bias in migratory pattern, except for a trend towards more female brackish-habitat residents (Table 2). A great proportion (44\%) of males was composed of silver eels captured during the downstream migration in fall. They were almost all freshwater residents or $\mathrm{A}_{\mathrm{BF}}$. Finally, age-at-migration was the same among sexes (chi-square, $\chi^{2}=1.09, p=0.90$ ): $71 \%$ of females and $67 \%$ of males changed habitat at Age 2+ or 3+.

Finally, the number of eels that changed habitat was the same among years (Kruskal-Wallis test, 16.52, $\mathrm{p}=$ 0.28 ), and the direction of the movement was not related to the year (Kolmogorov-Smirnov, $\mathrm{p}=0.88$ ), suggesting the absence of a particular climatic event or eel density that could have increased movements between habitats in a given year.

\section{Consequences of the migratory patterns}

Both length and body mass at age relations were significantly greater for eels spending more time in brackish water (Group 2) than for eels spending more time in freshwater habitats (Group 1) (length-at-age: $F=35.80$, $\mathrm{p}<0.01$; weight-at-age: $F=56.79, \mathrm{p}<0.01$; Figs. $3 \& 4$ ). When back-calculated sizes were compared after habitat switch, eels that remained in the brackish habitat (BR) were larger than eels that moved to freshwater (FR or $\mathrm{A}_{\mathrm{BF}}$ ) (Kolmogorov-Smirnov, all $\left.\mathrm{p}<0.05\right)$. This difference was maintained in subsequent years.

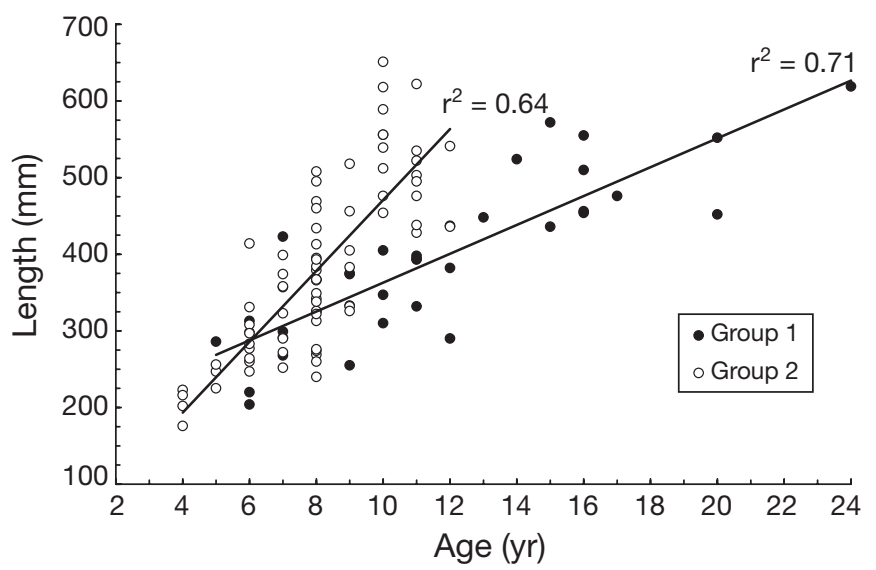

Fig. 3. Anguilla rostrata. Relationship between body length and age for yellow female eels from 2 groups of migratory pattern. Group 1: FR and $A_{B F}$ eels; Group 2: $B R, A_{F B}$ and $\mathrm{A}_{\mathrm{ND}}$ eels

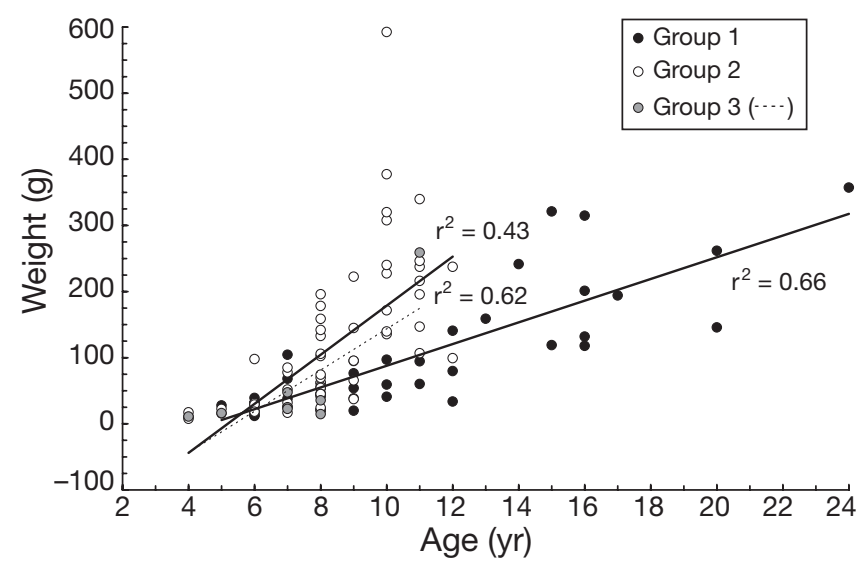

Fig. 4. Anguilla rostrata. Relationship between weight and age for yellow female eels from 3 groups of migratory pattern. Group 1: FR and $A_{B F}$ eels; Group 2: BR and $A_{N D}$ eels; Group 3: $A_{F B}$ eels

\section{DISCUSSION}

\section{Migratory patterns during the growth phase}

Constraints imposed by the logistics of fishing in different habitats lead to a sampling effort that was not proportional to the relative abundance of eels in different habitats. Eels captured in the estuary were most probably under-represented compared with their relative abundance in the overall watershed. Therefore, proportions of the migratory patterns presented in this study cannot be interpreted at the scale of the entire St. Jean River system. Nevertheless, comparison of proportions among habitats provides a picture of trends in migratory patterns. Overall, amphidromous (mostly $\mathrm{A}_{\mathrm{ND}}$ ) and brackish resident eels are probably far more more abundant than revealed here.

\section{Amphidromy}

Among the 162 eels sampled in the St. Jean River watershed, we predominantly observed an amphidromous migratory pattern $(42 \%)$ during the yellow-stage growth phase, followed by brackish $(38 \%)$ and freshwater $(20 \%)$ residence behavior. Here we refer specifically to marine amphidromy, whereby diadromous fish that spawn at sea may exploit both freshwater and marine environments for feeding and growth (Gross et al. 1988). A predominance of eels that move once or several times between habitats of different salinity has been reported for many eels species and regions (Anguilla rostrata: Jessop et al. 2002, 2006, Morrison et al. 2003; A. anguilla: Daverat et al. 2005; A. japonica: Tsukamoto \& Arai 2001, Shiao et al. 2003; A. dieffenbachii: Arai et al. 2004). In our study, we found migrant 
eels throughout the watershed, an observation that is consistent with other studies (Tsukamoto \& Arai 2001, Lamson et al. 2006). However, amphidromous eels captured in the river during summer were sampled in the lower reach, as reported by Shiao et al. (2003). This concords with the decreasing gradient of residency from upstream to downstream documented for $A$. anguilla by Daverat \& Tomás (2006) in the Gironde watershed (France). Unlike observations by Morrison et al. (2003) and Cairns et al. (2004), but in agreement with Daverat \& Tomás' (2006) results, we found few eels $(n=10)$ that returned to the estuary after freshwater residence $\left(A_{F B}\right)$. The age of habitat switching for migrant eels approximately 3 yr old was similar to that observed in other studies (reviewed by Daverat et al. 2006).

\section{Freshwater residence}

Among St. Jean eels that entered freshwater, few settled in the river; the majority migrated further upstream to reach the lake and remained there until their spawning migration. The freshwater residents, constituting the typical catadromous life history, were found mainly in Sirois Lake (45\%), located $80 \mathrm{~km}$ upstream of the estuary. Another 33\% were sampled during fall in the lower part of the river and were mostly at the silver stage. More than half $(60 \%)$ of the small number of eels $(n=10)$ captured in the different sectors of the river during summer were freshwater residents. However, during the spring downstream migration, we captured only 1 freshwater eel.

\section{Brackish residence}

Eels characterised as brackish water residents and captured in the river during the spring downstream migration, and probably also some of those sampled in the estuary during summer and fall, may in reality be seasonal migrants instead of brackish water residents. Otolith $\mathrm{Sr}: \mathrm{Ca}$ ratios indicated brackish residence behavior for the majority of eels captured in the estuary $(60 \%)$. However, more than half of the BR eels (51\%) that we captured were obtained from the river during the spring downstream migration. These results are surprising because otolith $\mathrm{Sr}$ :Ca ratio values did not correspond to the water $\mathrm{Sr}$ : Ca concentrations and salinity $(0 \%)$ at the capture site. Brackish/marine residents are usually found in estuaries or at sea (Cairns et al. 2004, Daverat \& Tomás 2006, Lamson et al. 2006). A telemetry and tagging study demonstrated that in the St. Jean River, eels of the spring downstream migration mostly move to the estuary for feeding during summer, and probably come back to the river at the end of fall for overwintering (Thibault et al. 2007). The same kind of seasonal migrations have been observed in many rivers of Nova Scotia, where large numbers of yellow eels move upstream from the saltwater estuary during fall to overwinter in freshwater lakes and then migrate downstream in spring (Medcof 1969, Jessop 1987).

The overwintering period for St. Jean River eels probably lasts about 4 to 6 mo. During this time, the river and lakes are covered by ice and water temperature is around $0^{\circ} \mathrm{C}$. Since feeding and growth are almost nil during the cold season at this northern latitude (Walsh et al. 1983), otolith growth is very restricted during this period (Umezawa \& Tsukamoto 1991, Radtke \& Fey 1996). Therefore, it seems likely that the freshwater Sr:Ca ratio signal is not recorded on otoliths among eels that undergo seasonal migrations between fresh and brackish waters. These results do not invalidate the microchemistry technique, but rather suggest a possible source of bias in interpreting $\mathrm{Sr}$ :Ca ratios under these particular climatological conditions.

\section{Inappropriate otolith edge ratios}

The missing record of freshwater wintering on the otoliths could explain the high rate of erroneous $\mathrm{Sr}: \mathrm{Ca}$ ratios observed at the otolith edge. This problem of innapropriate edge ratios has already been reported in other studies and may arise from (1) an artefact of the otolith preparation, e.g. failure to reach the exact otolith edge or a choice of a radius that is not the longest, (2) real movement that is too recent to be recorded on the otolith, or (3) varying environmental conditions (Jessop et al. 2002). In our case, the significantly higher frequency of these inappropriate edge ratios in brackish resident eels captured during the spring downstream migration leads us to suggest that they are mainly caused by an unrecorded, recent movement in cold freshwater. Elemental uptake into otoliths is not immediate (Elsdon \& Gillanders 2005). In American eels from Nova Scotia, a change in environmental salinity may take more than $31 \mathrm{~d}$ to register in the otolith at mean daily water temperatures of 13.8 to $23.0^{\circ} \mathrm{C}$, even in relatively fast-growing young eels, and perhaps much longer in slower-growing, older eels (Jessop et al. 2002). This is primarily because elements require time to pass through physiological barriers before being incorporated into otoliths (Elsdon \& Gillanders 2003). Moreover, 6 eels captured in the St. Jean River at the beginning of the spring downstream migration were kept in captivity in the river with little food for about $40 \mathrm{~d}$ (authors' unpubl. data). Otolith Sr:Ca ratio analyses categorised these fish as brackish 
residents because no freshwater $\mathrm{Sr}$ : Ca ratio signal was detected on the otolith. It thus appears possible that otolith microchemistry studies conducted in similar climatic conditions may have overestimated the number of brackish residents and misidentified potential seasonal migrants.

\section{Migratory plasticity in American eels: a conditional strategy?}

We could not demonstrate that differences in individual size or sex were associated with the adoption of a particular migratory tactic. Sizes of non-migrant and migrant eels prior to the age of the habitat switch were not significantly different; thus, small freshwater eels do not move to brackish water to promote their growth. We also found that the age at migration was not clearly related to a critical threshold size. Our results differ from those of Daverat \& Tomás (2006), who found that European eels that migrated from freshwater to brackish/marine water were larger at the time of movement than were freshwater resident eels of the same age. This difference may be explained in part by the fact that their sampling gear in freshwater tended to underrepresent small sizes (Daverat \& Tomás 2006). Finally, we demonstrated that the choice of a growth habitat was not related to sex because neither females nor males demonstrated a tactic preference, as found by Jessop et al. (2006). Therefore, it appears that size, age and sex may not control the migratory patterns of American eels of the St. Jean River watershed. However, it is possible that the absence of size effect on the choice and timing of migratory patterns might be due to the large errors associated with back-calculation techniques (Holmgren 1996). Additional sources of error may have been caused if eels categorized as brackish water residents in fact included seasonal migrants. The adoption of a seasonal migratory behavior may involve a particular threshold size and/or age that could not be documented because these habitat switches were not visible on otoliths.

Habitat switches occurred predominatly around Age 3 (Daverat et al. 2006, this study), and thus there seems to be a favourable window for migration at this time. This suggests that other phenotypic variables may act as threshold variables in a conditional strategy. For example, migratory decisions may be related to the individual's hormonal condition at some critical time that may favour migration, e.g. thyroxine (T4), which is involved in locomotor activities (Castonguay et al. 1990), or prolactin, which determines osmoregulation capacities (Olivereau 1975). Further research is required to explore the conditional nature of these migratory tactics.

\section{Consequences of the growth habitat on biological characteristics}

Although biological characteristics documented here did not appear to induce a particular migratory tactic, such differences arose as a consequence of the migratory pattern chosen by eels, as proposed by Morrison et al. (2003). Our analyses demonstrated that freshwater residents and eels that entered in freshwater after only a few years spent in the estuary grew slower than eels that lived in brackish water for most or all of their lives. These results confirm our hypothesis that the use of estuarine ecosystems increases the rate of growth and maturation because of their higher productivity. The biological productivity of the St. Jean River watershed was not measured in this study. However, it was shown in other Gaspesian rivers discharging to barbuilt estuaries that chl a concentrations are much higher in the brackish estuary (maximum of $3 \mathrm{mg} \mathrm{m}^{-3}$ ) than in the freshwater river (less than $0.3 \mathrm{mg} \mathrm{m}^{-3}$ on average) (Gagnon 2002). Similar differential growth rates among habitats were previously demonstrated in other studies (Morrison et al. 2003, Édeline \& Élie 2004, Jessop et al. 2006). Édeline \& Élie (2004) concluded that higher growth rates in saltwater are not related to the higher avaibility of food in more productive marine environments, but to a greater appetite in saltwater probably caused by some hormonal production. However, their study was conducted on glass eels and it is possible that feeding behaviors are not controlled in the same way in older stages.

It must be mentioned that the potential presence of seasonal migrants among brackish resident eels may have contributed to an underestimation of the benefits of estuarine feeding on eels' size and weight. Migration between brackish and freshwater involves high costs in terms of energy, stress and osmoregulation (Gross 1987, Castonguay et al. 1990, Shiao et al. 2003). Therefore, seasonal migrants might exhibit a lower length-at-age and weight-at-age than brackish resident eels.

\section{Catadromy to amphidromy: eel evolution towards a new lifestyle}

Temperate eel species are believed to have evolved from tropical species that exhibit the typical catadromous life cycle, with a growth phase in freshwater habitats (Tsukamoto et al. 2002). McDowall (1987) demonstrated that catadromy tends to occur most frequently in the tropics. In a region where both temperate and tropical eel species co-exist, tropical eels Anguilla marmorata conserve their freshwater preferences, while the temperate eel A. japonica uses habi- 
tats of different salinities (Shiao et al. 2003). It is possible that temperate eel species initially colonised northern habitats owing to their need to find vacant niches not used by tropical eels (Shiao et al. 2003). Yet, if freshwater habitats are more productive than oceans near the tropics, the inverse occurs at northern latitudes (Gross 1987, Tsukamoto \& Arai 2001). The most important biological variable in explaining the presence and direction of diadromous migration is the relative availability of food (Gross 1987). We may thus speculate that some temperate eels may have begun to use estuaries and coastal waters to promote growth. To support this idea, Daverat et al. (2006) found that temperate eels living at higher latitudes exhibited a greater probability of remaining in the lower reaches of watersheds in brackish water than did eels living at lower latitudes. Amphidromy is defined as migration between the sea and freshwater during a regular phase of the life cycle and not for the purpose of breeding (McDowall 1987). Thus, northern eel species may be considered as marine/estuarine amphidromous fishes that spawn at sea. However, given the level of phenotypic plasticity that allows eels to exploit all types of habitat, a simple categorisation of their life cycle may be misleading.

Acknowledgements. The study was funded by the Natural Science and Engineering Research Council of Canada, the Ministère de l'Agriculture, des Pêcheries et de l'Alimentation du Québec and the Ministère des Ressources Naturelles et de la Faune du Québec. We are grateful to D. Fournier, V. Cauchon, D. Hatin, L. A. Julyan, V. Lavoie, F. Dubé and J. N. Bujold for their assistance on the field. We thank D. Deschamps and C. Gauthier for age determination. Finally, we thank D. Cairns, G. Winkler and R. Pouliot for their comments on earlier versions of the manuscript.

\section{LITERATURE CITED}

Arai T, Kotake A, Lokman PM, Miller MJ, Tsukamoto K (2004) Evidence of different habitat use by New Zealand freshwater eels Anguilla australis and A. dieffenbachii, as revealed by otolith microchemistry. Mar Ecol Prog Ser 266:213-225

Cairns DK, Shiao JC, Iizuka Y, Tzeng WN, MacPherson CD (2004) Movement patterns of American eels in an impounded watercourse, as indicated by otolith microchemistry. N Am J Fish Manag 24:452-458

Campana SE (1999) Chemistry and composition of fish otoliths: pathways, mechanisms and applications. Mar Ecol Prog Ser 188:263-297

Caron F, Fournier D, Cauchon V (2005) Travaux de recherche sur le saumon des rivières Saint-Jean et de la Trinité en 2004. Ministère des Ressources Naturelles et de la Faune, Direction de la Recherche sur la Faune, Québec

Castonguay M, Dutil JD, Audet C, Miller R (1990) Locomotor activity and concentration of thyroid hormones in migratory and sedentary juvenile American eels. Trans Am Fish Soc 119:946-956
Daverat F, Tomás J (2006) Tactics and demographic attributes in the European eel Anguilla anguilla in the Gironde watershed, SW France. Mar Ecol Prog Ser 307: 247-257

Daverat F, Thomas J, Lahaye M, Palmer M, Elie P (2005) Tracking continental habitat shifts of eels using otolith Sr/Ca ratios: validation and application to the coastal, estuarine and riverine eels of the Gironde-GaronneDordogne watershed. Mar Freshw Res 56:619-627

Daverat F, Limburg KE, Thibault I, Shiao JC and 5 others (2006) Phenotypic plasticity of habitat use by three temperate eel species Anguilla anguilla, A. japonica and A. rostrata. Mar Ecol Prog Ser 308:231-241

Édeline E, Élie P (2004) Is salinity choice related to growth in juvenile eel Anguilla anguilla? Cybium 28:77-82

Elsdon TS, Gillanders BM (2003) Reconstructing migratory patterns of fish based on environmental influences on otolith chemistry. Rev Fish Biol Fisher 13:219-235

Elsdon TS, Gillanders BM (2005) Strontium incorporation into calcified structures: separating the effects of ambient water concentration and exposure time. Mar Ecol Prog Ser 285:233-243

Gagnon M (2002) Étude des caractéristiques biophysiques, des usages et du potentiel myicole de six barachois du sud de la Gaspésie. Parts I and II. Biorex Inc. Report presented to the Societé de developpement de l'industrie maricole (SODIM), Québec

Gross MR (1987) Evolution of diadromy in fishes. Am Fish Soc Symp 1:14-25

Gross MR (1996) Alternative reproductive strategies and tactics: diversity within sexes. Trends Ecol Evol 11:92-98

Gross MR, Coleman RM, McDowall RM (1988) Aquatic productivity and the evolution of diadromous fish migration. Science 239:1291-1293

Hansen RA, Eversole AG (1984) Age, growth, and sex ratio of American eels in brackish-water portions of a South Carolina river. Trans Am Fish Soc 113:744-749

Helfman GS, Facey DE, Hales LS Jr, Bozeman EL Jr (1987) Reproductive ecology of the American eel. Am Fish Soc Symp 1:42-56

Holmgren K (1996) Otolith growth scaling of the eel, Anguilla anguilla (L.), and back-calculation errors revealed from alizarin labelled otoliths. Nord J Freshw Res 72:71-79

Jessop BM (1987) Migrating American eels in Nova Scotia. Trans Am Fish Soc 116:161-170

Jessop BM, Shiao JC, lizuka Y, Tzeng WN (2002) Migratory behaviour and habitat use by American eels Anguilla rostrata as revealed by otolith microchemistry. Mar Ecol Prog Ser 233:217-229

Jessop BM, Shiao JC, Iizuka Y, Tzeng WN (2006) Migration of juvenile American eels Anguilla rostrata between freshwater and estuary, as revealed by otolith microchemistry. Mar Ecol Prog Ser 310:219-233

Kraus RT, Secor DH (2004) Incorporation of strontium into otoliths of an estuarine fish. J Exp Mar Biol Ecol 302: 85-106

Lamson HM, Shiao JC, Iizuka Y, Tzeng WN, Cairns DK (2006) Movement patterns of American eels (Anguilla rostrata) between salt and fresh water in a coastal watershed, based on otolith microchemistry. Mar Biol 149:1567-1576

McDowall RM (1987) Evolution and importance of diadromy, the occurrence and distribution of diadromy among fishes. Am Fish Soc Symp 1:1-13

Medcof JC (1969) Fishermen's reports of freshwater and saltwater migrations of Nova Scotia eels (Anguilla rostrata). Can Field Nat 83:132-138

Morrison WE, Secor DH, Piccoli PM (2003) Estuarine habitat use 
by Hudson River American eels as determined by otolith strontium:calcium ratios. Am Fish Soc Symp 33:87-100

Olivereau M (1975) Dopamine, prolactin control and osmoregulation in eels. Gen Comp Endocr 26:550-561

Radtke R, Fey DP (1996) Environmental effects on primary increment formation in the otoliths of newly-hatched Arctic charr. J Fish Biol 48:1238-1255

SAS (2001) SAS Institute. Language guide. Release 6.03. SAS Institute, Cary, NC

Secor DH, Rooker JR (2000) Is otolith strontium a useful scalar of life cycles in estuarine fishes? Fish Res 46:359-371

Shiao JC, Iizuka Y, Chang CW, Tzeng WN (2003) Disparities in habitat use and migratory behavior between tropical eel Anguilla marmorata and temperate eel A. japonica in four Taiwanese rivers. Mar Ecol Prog Ser 261:233-242

Shiao JC, Lozys L, Iizuka Y, Tzeng WN (2006) Migratory patterns and contribution of stocking to the population of European eel in Lithuanian waters as indicated by otolith Sr:Ca ratios. J Fish Biol 69:749-769

Thériault V, Dodson JJ (2003) Body size and the adoption of a migratory tactic in brook charr. J Fish Biol 63:1144-1159

Thibault I (2006) Étude du comportement migratoire de l'anguille d'Amérique (Anguilla rostrata) dans la rivière Saint-Jean (Gaspé). MS thesis, Laval University, Quebec

Editorial responsibility: Howard Browman (Associate Editorin-Chief), Storebø, Norway
Thibault I, Dodson JJ, Caron F (2007) Yellow stage American eel movements determined by microtagging and acoustic telemetry in the St. Jean River watershed, Gaspé (Quebec, Canada). J Fish Biol (in press)

Tsukamoto K, Arai T (2001) Facultative catadromy of the eel Anguilla japonica between freshwater and seawater habitats. Mar Ecol Prog Ser 220:265-276

Tsukamoto K, Aoyama J, Miller MJ (2002) Migration, speciation, and the evolution of diadromy in anguillid eels. Can J Fish Aquat Sci 59:1989-1998

Tzeng WN (1996) Effects of salinity and ontogenetic movements on strontium:calcium ratios in the otoliths of Japanese eel, Anguilla japonica Temminck and Schlegel. J Exp Mar Biol Ecol 199:111-122

Tzeng WN, Wang CH, Wickström H, Reizenstein M (2000) Occurrence of the semi-catadromous European eel Anguilla anguilla in the Baltic Sea. Mar Biol 137:93-98

Umezawa A, Tsukamoto K (1991) Factors influencing otolith increment formation in Japanese eel, Anguilla japonica T. \& S., elvers. J Fish Biol 39:211-223

Walsh PJ, Foster GD, Moon TW (1983) The effects of temperature on metabolism of the American eel Anguilla rostrata (LeSueur): compensation in the summer and torpor in the winter. Physiol Zool 56:532-540

Submitted: November 3, 2006; Accepted: February 20, 2007 Proofs received from author(s): July 22, 2007 